\title{
Comparative Study of Flooding Area Detection with SAR Images based on Thresholding and Difference Images Acquired Before and After the Flooding
}

\author{
Kohei Arai \\ Faculty of Science and Engineering \\ Saga University, Saga City \\ Japan
}

\begin{abstract}
Comparative study of flooding area detection with Synthetic Aperture Radar (SAR) images based on thresholding and difference images acquired before and after the flooding is conducted. Method for flooding, landslide and sediment disaster area detections with SAR is proposed. The following two different methods for flooding detection are common. It is not so easy to determine a threshold for the thresholding method while subtraction method between before and after images of a disaster occurrence has the disadvantage that false disaster areas are detected due to a variation of ground cover targets. Therefore, a comparative study between both methods is required. Its application is demonstrated for the disaster which is occurred in Saga Prefecture, Japan due to a long term of heavy rain during from the begging of August to the middle of August in 2021. Through experiments with Sentinel-1 SAR imagery data, it is found that the proposed method works well for the detection of the disaster.
\end{abstract}

Keywords_Flooding; landslide; sediment disaster; heavy rain; image quality; Synthetic Aperture Radar; SAR; sentinel-1 SAR; thresholding; difference images between before and after disaster

\section{INTRODUCTION}

Sentinel Asia means "Asia Observer", which is an activity to utilize space technology, especially remote sensing technology, for disaster management in the Asia-Pacific region. This initiative is being promoted in cooperation with space agencies in the Asia-Pacific region, including Japan, and with disaster prevention agencies in this region, and has become an international framework.

Disaster information such as images of disaster-stricken areas observed by earth observation satellites is available on the Internet. It also has a function called Web-GIS (Geographic Information System), which allows satellite images to be superimposed and displayed on a map. Activities include observing the situation in the disaster area as soon as possible after a disaster occurs and providing related information for forest fires and floods as a regular monitoring activity. In addition, meteorological satellite (MTSAT-1R) images are available on Web-GIS.

Not only Sentinel Asia, but also, other remote sensing satellite data-based disaster area detection is getting more popular. There are some methods for the disaster area detection with SAR imagery data. One of those is based on thresholding of the SAR image which is acquired after disaster. This is a straightforward method. The other method is based on difference images which are acquired before and after disaster. On the other hand, there is another method based on deep learning with training samples of input SAR images and truth data on disaster. In this paper, a comparative study is conducted between thresholding-based and difference imagebased methods. These methods do not require truth data on disaster occurred areas.

Also, in this paper, some examples of disaster areas, flooding areas, land slide areas, sediment disaster areas detections with Sentinel-1 SAR data are demonstrated. The heavy rains in August 2021 are estimated to have damaged 3,000 houses, and more than 200 landslides such as slope collapses and landslides. According to the prefecture, four men and women in their 60s and 80s were injured in this heavy rain in Saga City and Kanzaki City. Both are minor injuries.

As for the damage to the houses, one building was completely destroyed and one was partially destroyed by the debris flow that occurred in the Shiwaya district of Kanzaki Town, Kanzaki City. Inundation above and below the floor has been confirmed in approximately 3000 buildings in 15 cities and towns.

In some areas, investigations are still ongoing, and the number of floods is expected to increase further. In addition, rivers and revetments in 155 locations throughout the prefecture have collapsed, and sediment-related disasters such as slopes, shoulder collapses, landslides, and landslides have been confirmed in approximately 220 locations. Even August 17, eight households in the Yamada area of Miyaki Town have been instructed to ensure emergency safety, and evacuation orders have been issued to some areas of Takeo City and Ureshino City, and as of 4:00 pm, 198 people from 95 households have been evacuated.

Record heavy rains continued, and on the 14th of August 2021, landslides and floods occurred one after another in Saga prefecture. In the mountains, the back mountains collapsed and knocked down the huts, and in the flatlands, floods were seen here and there, stopping the flow of people and goods. With the issuance of a heavy rain special warning for the fourth consecutive year in the prefecture, some people are confused by the repeated warnings of "heavy rain once every few decades." 
In the next section, related research works are described followed by research background and theoretical background. Then, the proposed method is described followed by some experiments are described together with conclusion and some discussions.

\section{RELATED RESEARCH WORK}

There are the following disaster related papers:

Present status for disaster observation systems working group is reported [1]. Also, four dimensional GIS and its application to disaster monitoring with satellite remote sensing data is proposed [2].

An expectation to remote sensing for disaster management is reported [3]. Meanwhile, the conference on GIS and application of remote sensing to disaster management four dimensional GIS and its application to disaster monitoring with satellite remote sensing data is discussed [4].

The current status on disaster monitoring with satellites in Japan is reported [5]. Meantime, the joint symposium on disaster management between United Nation and Japan-US Science/Technology and Space Application Program is reported [6].

An expectation on remote sensing technology for disaster management and response is announced [7]. On the other hand, Virtual Center for Disaster Management is proposed [8]. Meanwhile, opening remarks of satellite-based disaster management is made [9].

Disaster related activities are reported [10]. Meanwhile, internet GIS and disaster information clearing house is proposed [11].

Opening address of the disaster management symposium is made [12]. Also, virtual center for disaster management is proposed [13]. Meantime, joint research on disaster management is proposed [14].

URL search engine with text search tools for disaster mitigation is created [15]. Meanwhile, four-dimensional GIS system through internet is proposed [16]. Visualization of disaster information derived from Earth observation data is proposed [17].

Java based image processing and analysis software package is created [18]. On the other hand, internet Geographic Information System (GIS) is created [19]. Meanwhile, disaster related URL search engine with queries in a natural language is proposed [20].

Disaster monitoring with ASTER onboard Terra satellite is conducted [21]. Also, clearing house for disaster management is created [22]. In the meantime, ICT technology for disaster mitigation (Tsunami warning system) is proposed [23].

Cellular automata-based approach for prediction of hot mudflow disaster area is proposed [24]. Meanwhile, simulation of hot mudflow disaster with cellular automata and verification with satellite imagery data is conducted [25].

Backup communication routing through Internet Satellite, WINDS, for transmission of disaster relief data is proposed
[26] together with backup communication routing through Internet satellite WINDS for transmission of disaster relief data [27].

Two-dimensional cellular automata approach for disaster spreading proposed [28]. Also, disaster mitigation is overviewed as a Visiting Scholar, World Class University [29].

Micro traffic simulation with unpredictable disturbance based on Monte Carlo simulation: effectiveness of the proposed agent cars of Sidoarjo hot mudflow disaster is conducted [30] together with probabilistic cellular automatabased approach for prediction of hot mudflow disaster area and volume is proposed [31].

Two-dimensional CA approach for disaster spreading is proposed [32]. On the other hand, deceleration in the micro traffic model and its application to simulation for evacuation from disaster area is proposed [33].

Cellular automata approach for disaster propagation prediction and required data system in GIS representations is proposed [34] together with cellular automata for traffic modelling and simulation in a situation of evacuation from disaster areas [35].

New approach of prediction of Sidoarjo hot mudflow disaster area based on probabilistic Cellular Automata (CA) is proposed [36] together with cellular automata for traffic modeling and simulation in a situation of evacuation from disaster areas for cellular automata simplicity behind complexity [37].

Back-up communication routing through Internet satellite WINDS for transmitting of disaster relief data is proposed [38]. Also, sensor network for landslide monitoring with laser ranging system avoiding rainfall influence on laser ranging by means of time diversity and satellite imagery data-based landslide disaster relief is created [39].

Task allocation model for rescue disable persons in disaster area with help of volunteers is proposed [40]. Also, cell-based GIS as Cellular Automata (CA) for disaster spreading prediction and required data systems is created [41].

Deceleration in the evacuation from disaster area is modeled and validated [42]. On the other hand, cell-based GIS as cellular automata for disaster spreading predictions and required data systems is created [43].

Visualization of 5D assimilation data for meteorological forecasting and its related disaster mitigation utilizing VIS5D of software tool is attempted [44]. Meanwhile, vital sign and location/attitude monitoring with sensor networks for the proposed rescue system for disabled and elderly persons who need some help in evacuation from disaster areas is proposed [45].

Method and system for human action detection with acceleration sensors for the proposed rescue system for disabled and elderly persons who need some help in evacuation from disaster areas is created [46]. Meanwhile, method and system for human action detection with acceleration sensors for the proposed rescue system for disabled and elderly persons 
who need a help in evacuation from disaster areas is proposed [47].

Disaster relief with satellite based Synthetic Aperture Radar data is proposed [48]. Meanwhile, Sentinel 1A SAR data analysis for disaster mitigation in Kyushu is presented [49].

Flooding and oil spill disaster relief using Sentinel of remote sensing satellite data is reported [50]. Convolutional neural network considering physical processes and its application to disaster detection is proposed [51].

Method for rainfall rate estimation with satellite-based microwave radiometer data is proposed for detection of flooding area [52]. On the other hand, flood damage area detection method by means of coherency derived from interferometric SAR analysis with Sentinel-1A SAR is proposed and validated with the truth data of flooding which occurred in Oita, Kyushu, Japan [53],

\section{ReSEARCh BACKgRound AND PROPOSED Method}

\section{A. Intensive Study Areas and Weather Condition}

Heavy rains started from 11 August 2021 and are continued for a week and ended on 17 August 2021. In more detail, Fig. 1(a) shows rainfall a day $(\mathrm{mm})$ and maximum rainfall rate an hour (mm/hour) in a day in the intensive study area of the Saga prefectural areas in Japan (Fig. 1(b)). Much $1000 \mathrm{~mm}$ of rainfall is observed within the week. Due to the rainfall, more than 3000 houses are damaged and more than 200 landslides such as slope collapses and landslides.

Fig. 2(a), (b), (c) shows the Sentinel-1 SAR imagery data which are acquired on 3 (before the rainfall), 15 (middle of the rainfall) and 28 (after the rainfall) August in 2021, respectively.

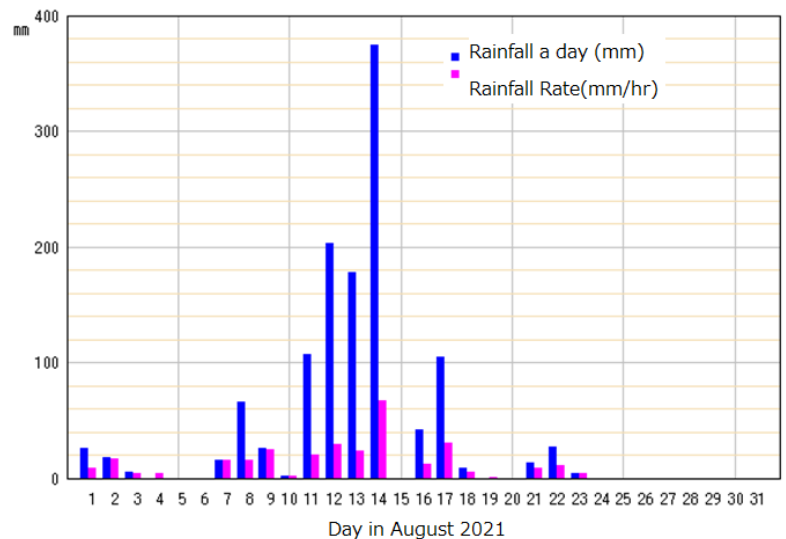

(a) Rainfall a Day (mm) and Maximum Rainfall Rate an Hour ( $\mathrm{mm} / \mathrm{hr})$ in a Day

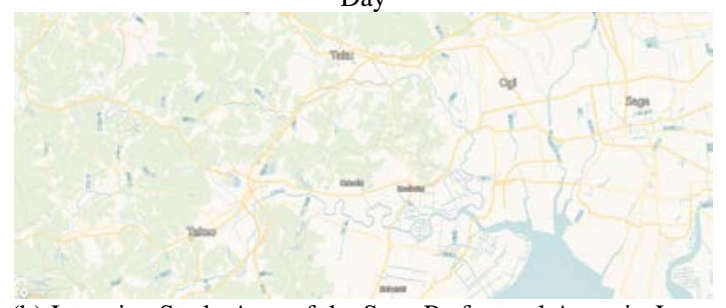

(b) Intensive Study Area of the Saga Prefectural Areas in Japan

Fig. 1. Intensive Study Area and Weather Condition (Heavy Rainfall in the Area).

\section{B. Methods for Disaster Detection}

1) Flooding area detection: It is possible to detect flooding areas to compare between Sentinel-1 SAR imagery data which are acquired before and after the rainfall. Backscattering coefficient of Sentinel-1 SAR imagery data is going down due to dielectric loss at the surface of the rainfall areas. Also, it is possible to detect the flooding areas by means of thresholding of the Sentinel-1 SAR imagery data which is acquired after the rainfall with the appropriate threshold.

2) Landslide, sediment disaster detection: On the other hand, it is possible to detect landslide, sediment disaster areas to compare between Sentinel-1 SAR imagery data which are acquired before and after the rainfall. Backscattering coefficient of Sentinel-1 SAR imagery data is going up because ground cover trees and grasses are disappeared at the surface of the landslide, sediment disaster areas.
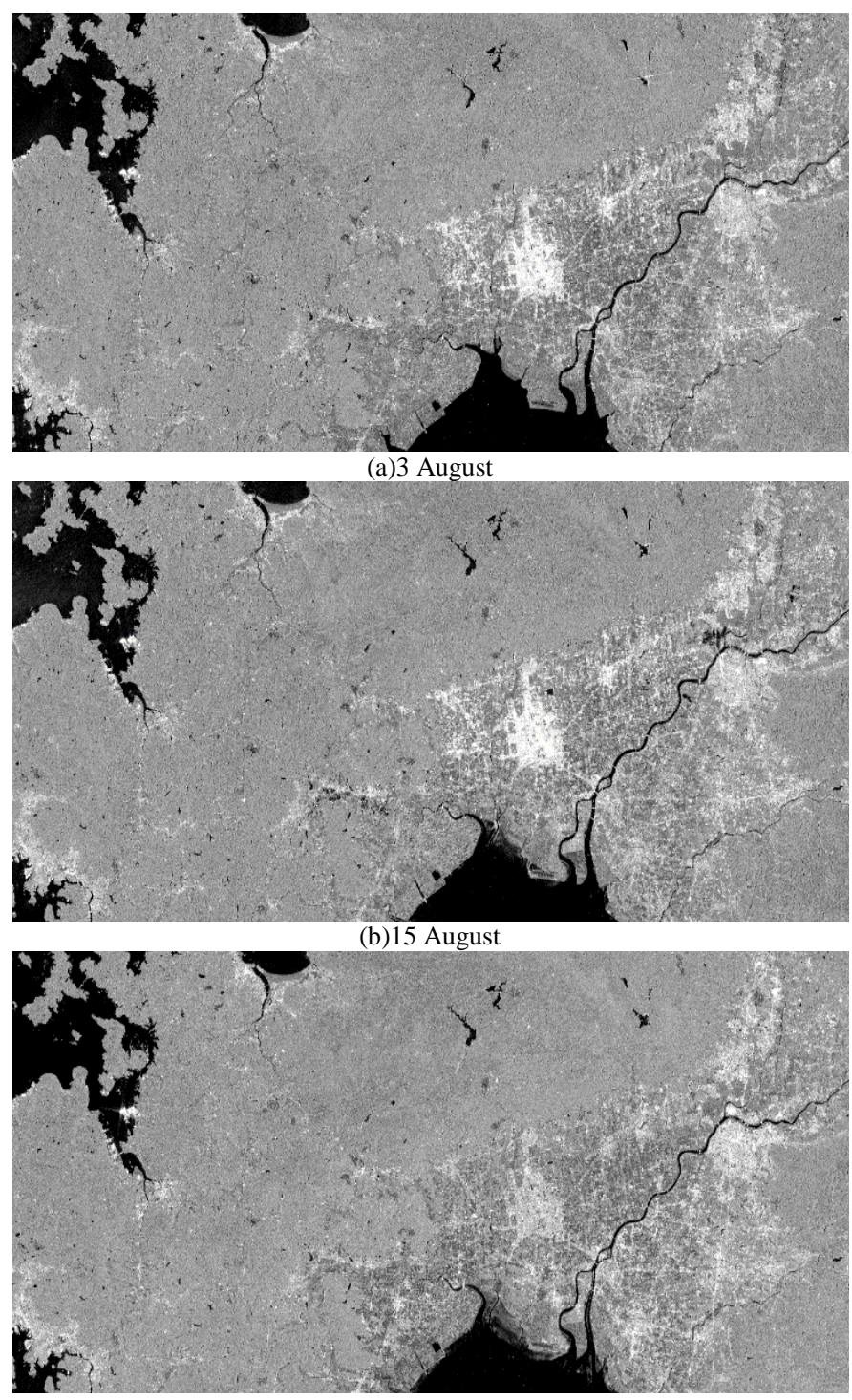

(c) 28 August

Fig. 2. Sentinel-1 SAR Imagery Data which are Acquired on 3 (before the Rainfall), 15 (Middle of the Rainfall) and 28 (after the Rainfall) August in 2021. 


\section{EXPERIMENT}

\section{A. Flooded Area Detection in Saga Prefecture}

Sentinel-1 SAR of 3 August (Fig. 2(a)) is subtracted from the Sentinel-1 SAR of 15 August (Fig. 2(b)). Then, the flooded areas are extracted. Fig. 3 shows the resultant image of the flooded areas. Dark portions of Fig. 3 image show the flooded areas and lakes, ponds. The flooded areas are situated almost everywhere in Saga prefecture.

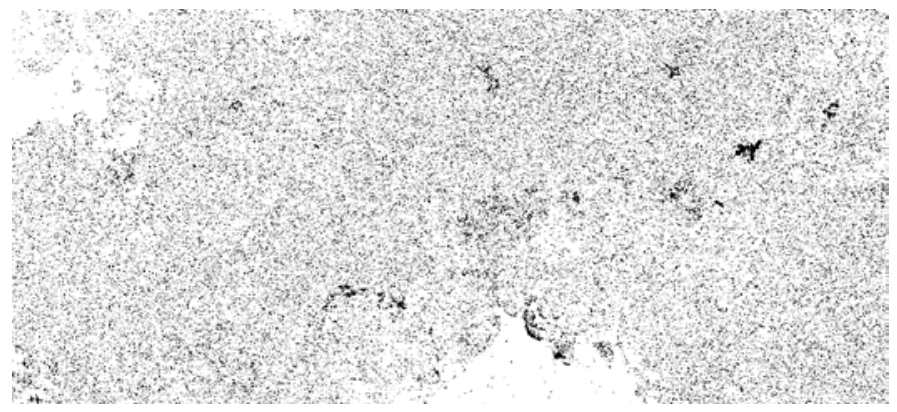

Fig. 3. Extracted Flooding Areas in Saga Prefecture due to Heavy Rainfall in August 2021.

\section{B. Flooded Area Detection in Omachi-Cho in Saga Prefecture}

Also, the flooded areas can be detected through thresholding of the Sentinel-1 SAR imagery data. Fig. 4(a) shows original Sentinel-1 SAR image of Omachi-Cho in Saga prefecture is acquired on 15 August 2021. The resultant image of detected flooding areas is shown in Fig. 4(b) while the Google map of the Omachi-Cho is shown in Fig. 4(c).

In 2019, some portions of Omachi-Cho are flooded due to relatively heavy rainfall. Fig. 5(a) shows Sentinel-1 SAR image of Omachi-Cho which is acquired on 15 August 2019.

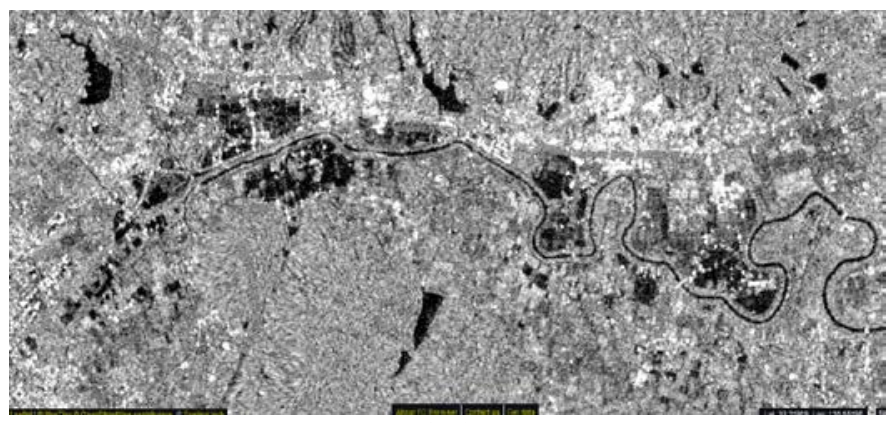

(a) Sentinel-1 SAR

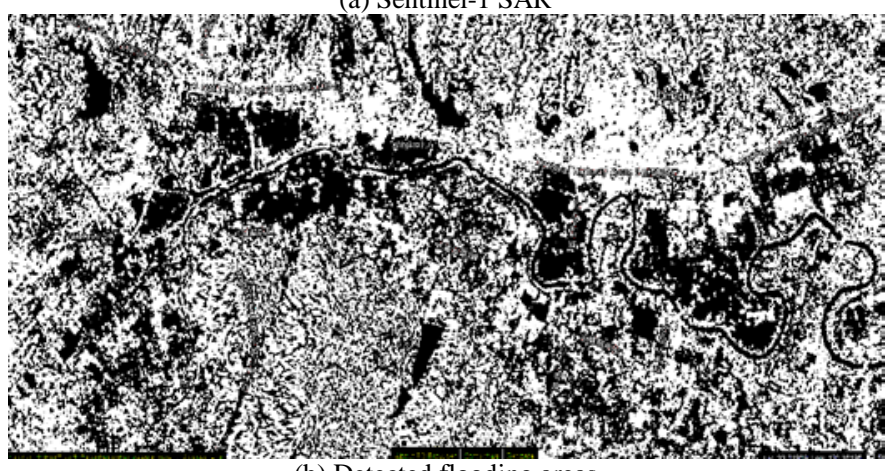

(b) Detected flooding areas

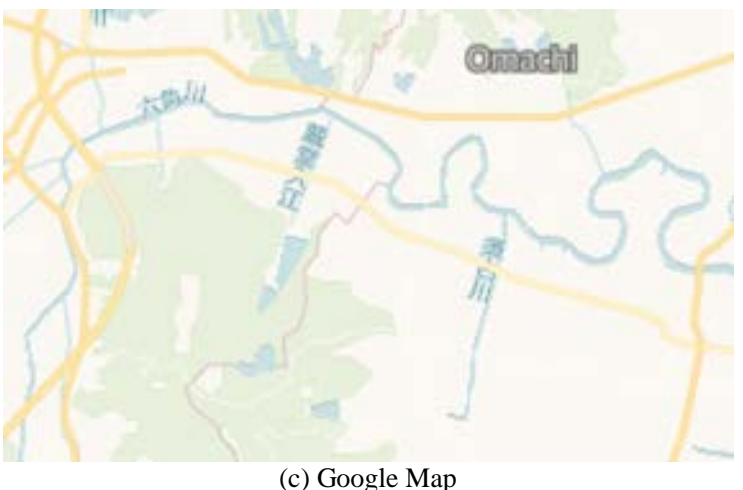

Fig. 4. Detection of Flooding Areas of Omachi-Cho, in Saga Prefecture due to the Heavy Rainfall in August 2021.

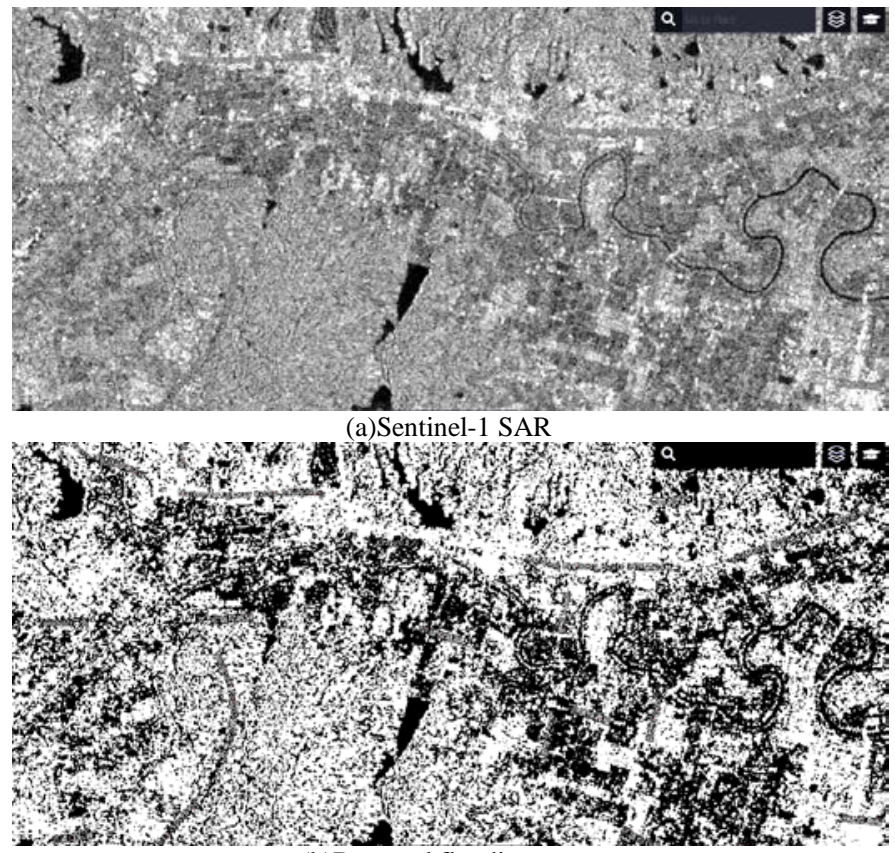

(b)Detected flooding areas

Fig. 5. Detection of Flooding Areas of Omachi-Cho in Saga Prefecture due to the Relatively Heavy Rainfall in August 2019.

On the other hand, Fig. 5(b) shows the flooding areas of Omachi-Cho detected through thresholding with the appropriate threshold. Through a comparison between Fig. 4(b) and Fig. 5(b), it is found that the flooding areas are almost coincident. Most of these matches the location of the old river channel. Also, it is found that the flooding areas of 2021 are larger than that of 2019. Furthermore, the depth of flooding is deeper in 2021 than that of 2019.

\section{Trend of Moisture in Omachi-Cho in 2021}

By using Sentinel-2 of optical sensor data, it is possible to estimated moisture. Trend analysis is made for moisture due to the heavy rainfall in August 2021. This moisture trend relates to the flooding closely. Fig. 6(a) shows the moisture index derived from Sentinel-2 of optical sensor data which is acquired on 23 June 2021. From the begging of August 2021, rainfall started so that moisture index of 2 August 2021 shows a lot of clouds as shown in Fig. 6(b). Fig. 6(c), (d), (e) shows moisture index of 7, 9, 19 August 2021. 


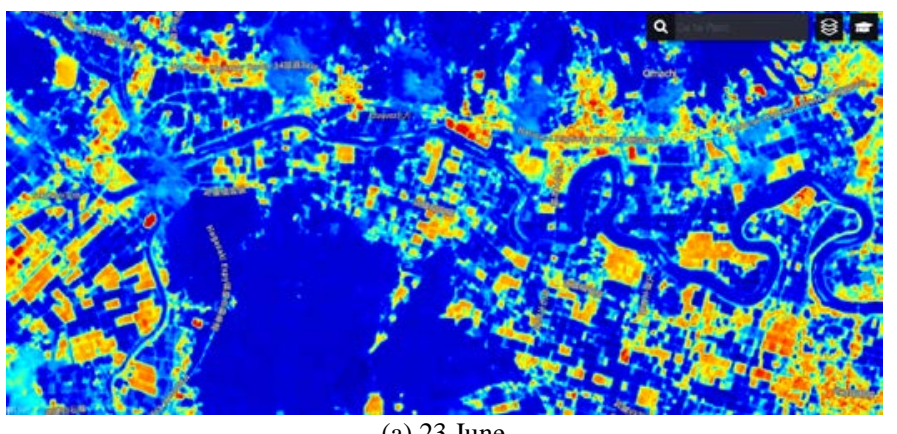

(a) 23 June
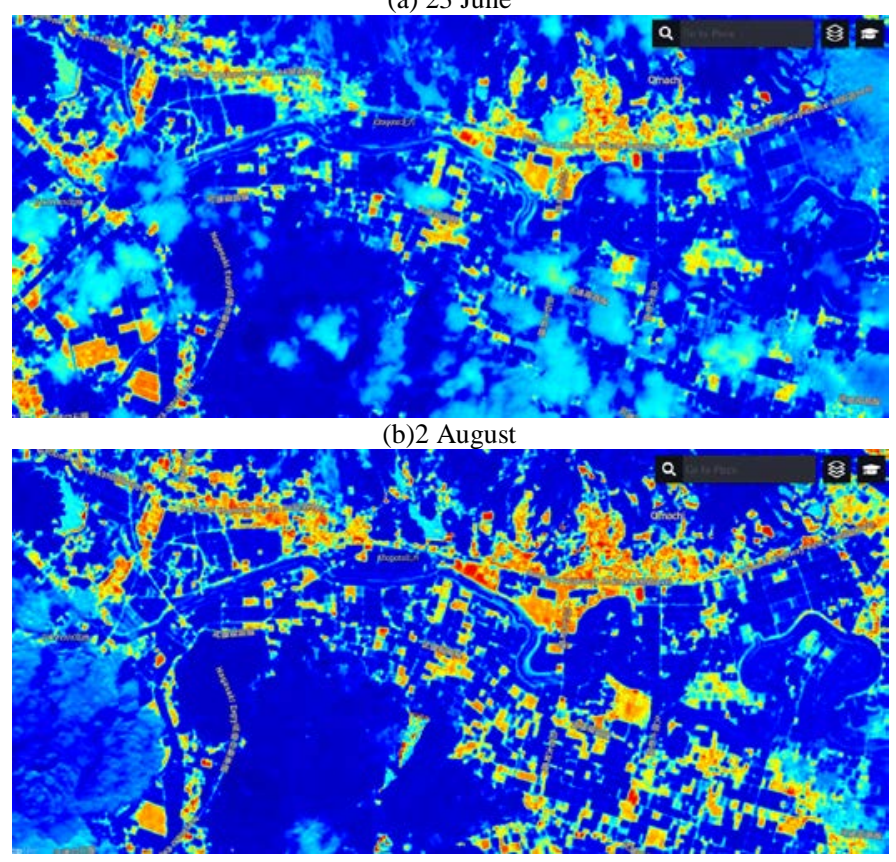

(c)7 August

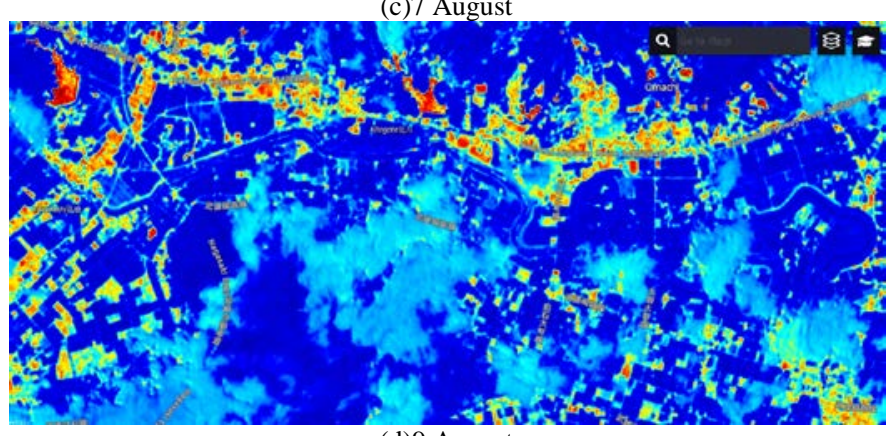

(d)9 August

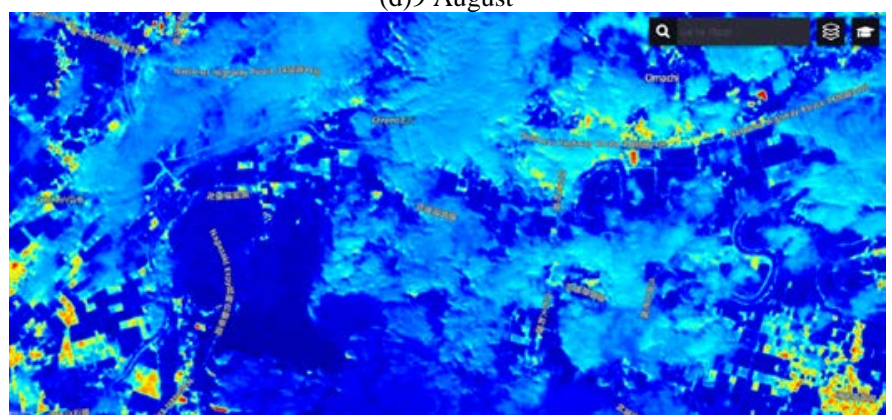

(e)19 August

Fig. 6. Moisture Index Trend of Omaci-Cho Derived from Sentinel-2 Optical Sensor of Imagery Data which is acquired in August 2021

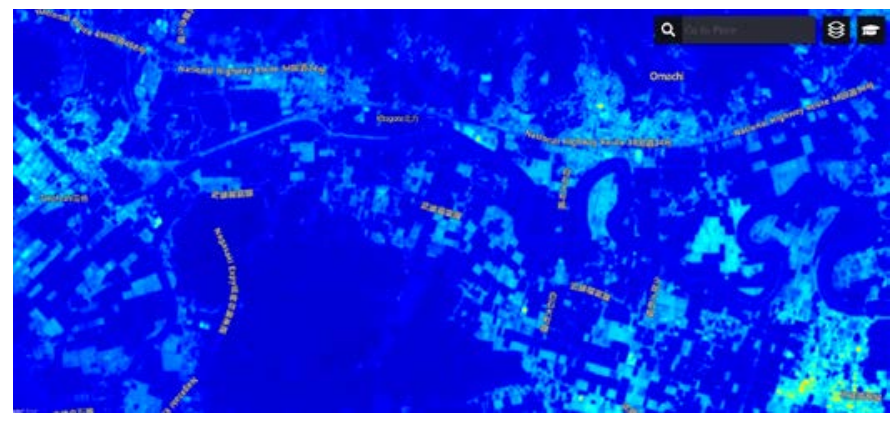

Fig. 7. Moisture Index of Omachi-Cho Areas in August 2019.

It is found that the Omachi-Cho areas are moisturized due to heavy rainfall in 2021. This is one of causes of the flooding and landslide as well as sediment disasters. Meanwhile, moisture index of Omachi-Cho areas derived from Sentinel-2 optical sensor which is acquired on 10 August 2019 is shown in Fig. 7. It is found that the Omachi-Cho areas are almost covered with clouds on 10 August 2019.

\section{Miyaki-Cho Minobaru Yamada, Saga Landslide}

The Yamada district of Miyaki-cho, Miyaki-gun, where "emergency safety assurance" has been issued for 25 people in 8 households because there is a risk of debris flow in the cold water (Shozu) river that flows through the Minobaru-Yamada district of Miyaki-cho. The evacuation shelter life will reach its fourth day on the 18th, and while the residents look tired, there is no prospect of cancellation because the weather will not recover. Residents are worried about when they can go home.

According to the Civil Engineering Office in the eastern part of the prefecture, the mountain surface on the right bank of the Kansui River, about $1.5 \mathrm{~km}$ upstream from the area, collapsed to block the river over a height of about 100 meters and a width of about 50 meters. Since the amount of water is large and heavy machinery cannot enter, staff members are walking into the site to prepare for surveying. The office says, "We are aiming for an early recovery, but the weather has not recovered, and we cannot predict the time."

Fig. 8(a) shows the location of collapsed area in Miyakicho, Minobaru Yamada, Saga on Google map due to the heavy rain in August 2021 while Fig. 8(b) shows the photo of the collapsed area.

On the other hand, Fig. 9(a) shows Sentinel-1 SAR image of the collapsed area of the Miyaki-Cho Minobaru Yamada, Saga Landslide which is acquired on 10 August 2021 while Fig. 9(b) shows that which is acquired on 16 August 2021. The longitude and latitude are $33.38762 \mathrm{~N}, 130.42950 \mathrm{E}$. The Sentinel-1 SAR images are VV polarization of decibel gamma0 data and is radiometric terrain corrected data. Yellow marks in Fig. 9 indicate the collapsed locations. Digital Number: DN of 10 August is 169 (255 in Maximum) while that of 16 August is 189. This implies that the backscattered coefficient of the collapsed area is raised from 169 to 189 due to the collapsing. 


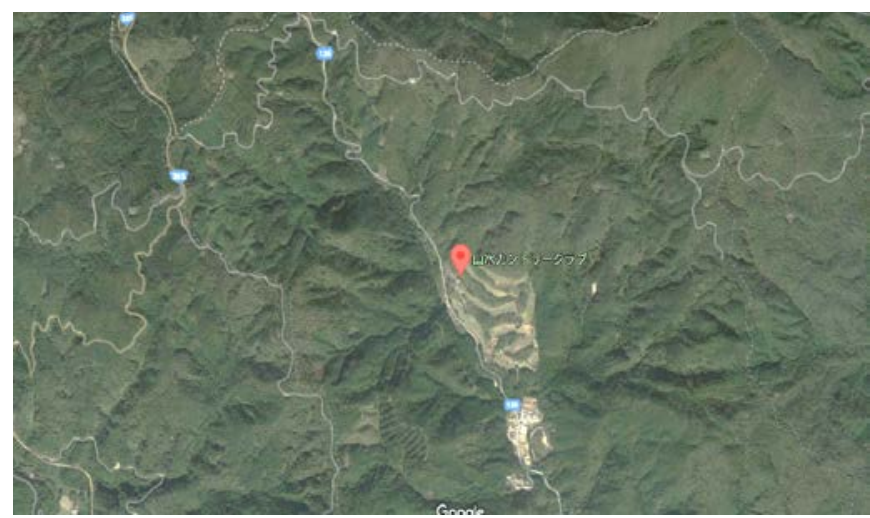

(a)Location of Collapsed Area

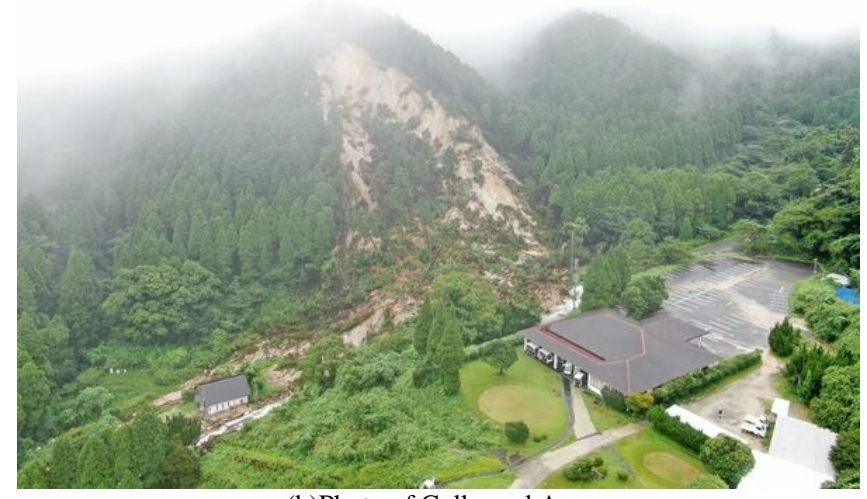

(b)Photo of Collapsed Area

Fig. 8. Miyaki-Cho Minobaru Yamada, Saga Landslide.

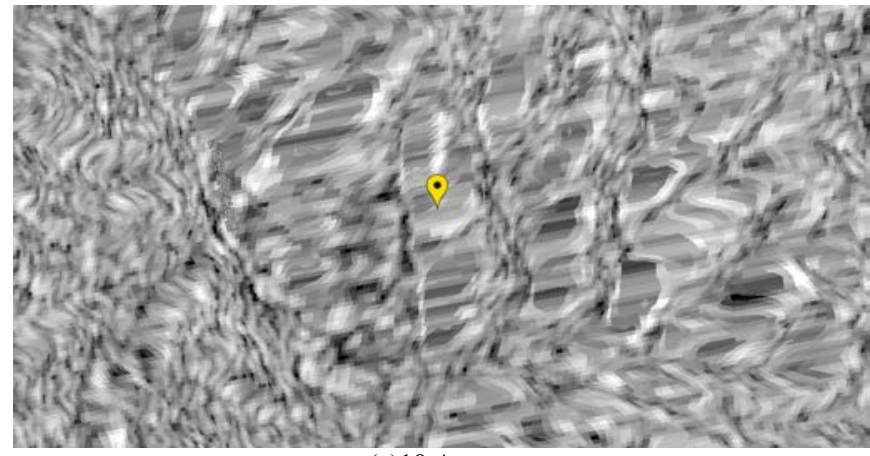

(a)10 August

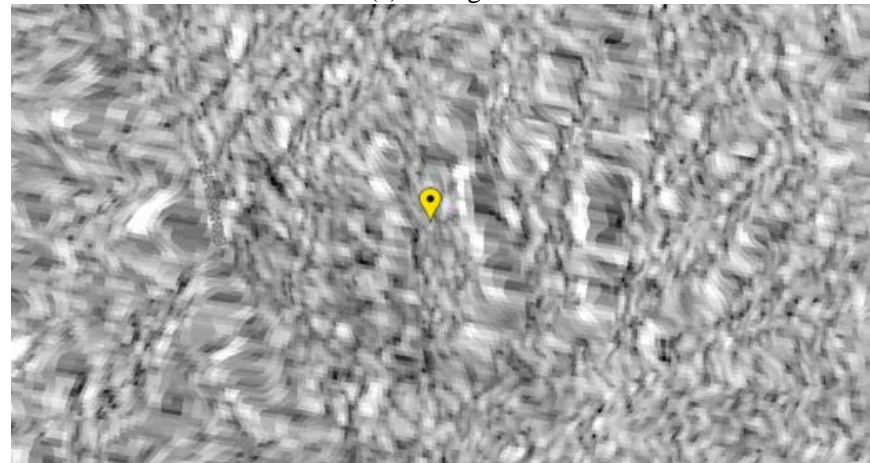

(b)16 August

Fig. 9. Sentinel-1 SAR Images which is acquired before and after the Collapsing Occurred at the Miyaki-Cho Minobaru Yamada, Saga in August 2021.

\section{E. Landslide which is Occurred at Yamato-Cho in Saga}

Regarding the record heavy rain that continued in Saga Prefecture from the 11 August 2021, the prefecture reported at the disaster countermeasures headquarters meeting held on the 18 August 2021 that a debris flow of about 1500 meters was occurring in Kuikei, Yamato-cho, Saga City. No human damage has occurred.

According to the Prefectural Forest Maintenance Division, debris flow from the forest flows into the agricultural land due to heavy rain and reaches under the elevated Nagasaki Expressway.

Fig. 10(a) shows the landslide area of Sentinel-1 SAR image which is acquired on 28 August 2021 (After the rainfall) which is occurred at Yamato-Cho in Saga due to the heavy rain in August 2021. Meanwhile, Fig. 10(b) and (c) shows that of 15 August (during the rainfall) and of 3 August (before the rainfall), respectively.

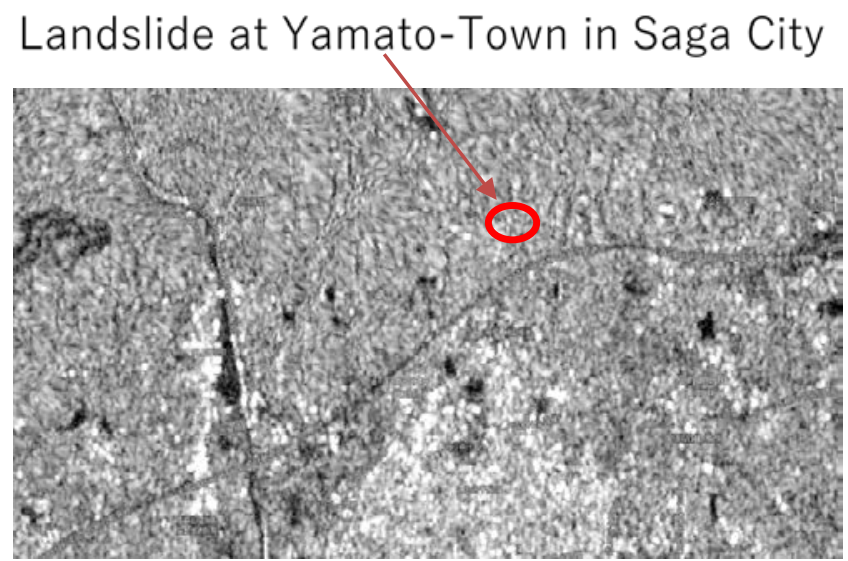

(a)28 August

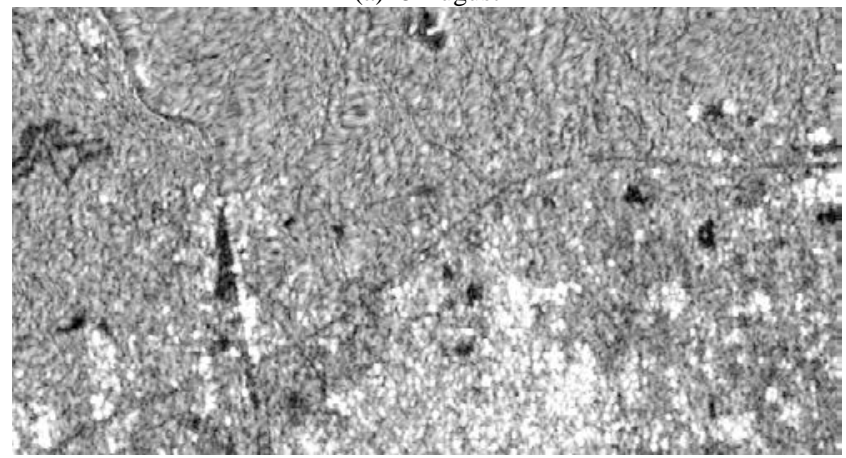

(b)15 August

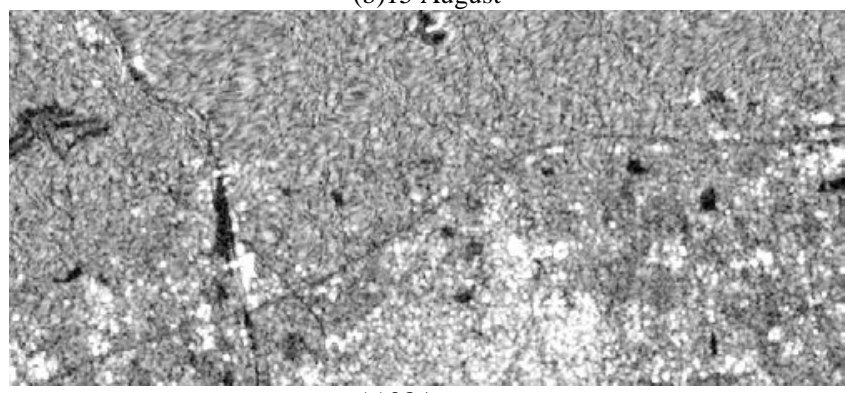

(c)28August

Fig. 10. Landslide which is occurred at Yamato-Cho in Saga due to Heavy Rain in August 2021 
Red circle shows the location of landslide area which is relatively high back scattering coefficients along with the line (white line in the red circle). There is no such high backscattering coefficient on 3 August as shown in Fig. 10(c). The white line of high back scattering coefficient pixels are increased as shown in Fig. 10(b).

Therefore, it is found that the landslide, collapsing, sediment disaster can be estimated with SAR imagery data onboard remote sensing satellites.

The result from this comparative study is summarized in the following Table I.

TABLE I. FEATURE OF THE DisAster AREA DETECTION METHODS FOR THE COMPARATIVE STUDY

\begin{tabular}{|l|l|l|}
\hline Method & Advantage & Disadvantage \\
\hline $\begin{array}{l}\text { Thresholding with } \\
\text { appropriate threshold }\end{array}$ & $\begin{array}{l}\text { Only an } \\
\text { appropriate } \\
\text { threshold is } \\
\text { needed }\end{array}$ & $\begin{array}{l}\text { It is hard to determine the } \\
\text { appropriate threshold }\end{array}$ \\
\hline $\begin{array}{l}\text { Subtraction of after } \\
\text { image from before image } \\
\text { of a disaster occurrence }\end{array}$ & $\begin{array}{l}\text { Just two imagery } \\
\text { data are required }\end{array}$ & $\begin{array}{l}\text { Non disaster areas are } \\
\text { sometime detected due to } \\
\text { ground cover targets } \\
\text { changes }\end{array}$ \\
\hline
\end{tabular}

\section{CONCLUSION}

Comparative study of flooding area detection with Synthetic Aperture Radar (SAR) images based on thresholding and difference images acquired before and after the flooding is conducted. It is concluded that the difference images-based method which are acquired before and after the disaster is superior to the thresholding-based method. Because the disaster situations are different by the areas in concern, single thresholding is not adequate for all the disaster areas. On the other hand, difference images-based method takes into account the different disaster situations by different areas.

Method for flooding, landslide and sediment disaster area detections with SAR is proposed. Such disaster which was occurred in Saga Prefecture, Japan due to a long term of heavy rain during from the begging of August to the middle of August in 2021 is analyzed with the proposed method. Through experiments with Sentinel-1 SAR imagery data, it is found that the proposed method works well for the detection of the disaster. It is also found that the landslide, collapsing, sediment disaster can be estimated with SAR imagery data onboard remote sensing satellites.

Moisture trend analysis can be done with Sentinel-2 optical sensor data. This is one of causes of flooding, landslide and sediment disasters. It is also confirmed that the proposed two methods for flooding, landslide and sediment disaster detection (before disaster occurred image subtracted by after disaster occurred image, and thresholding of after disaster occurred image with appropriate threshold) works well.

\section{FUTURE RESEARCH WORK}

In the future, it will be demonstrated for frequent observation of SAR imagery data. Sentinel-1 SAR imagery data can be acquired within 5 days (Revisit cycle of the one Sentinel-1 satellite is 10 days and there are two Sentinel-1 satellites, a and b). There are on-going projects of SAR constellations such as QPS/SAR-X.

\section{ACKNOWLEDGMENT}

The author would like to thank Professor Dr. Hiroshi Okumura and Professor Dr. Osamu Fukuda for their valuable discussions.

\section{REFERENCES}

[1] Kohei Arai, Present Status for Disaster Observation Systems Working Group, Proceedings of the 5th Japan-US Space Research Cooperation Conference, Hawaii, Nov. 1995.

[2] Kohei Arai, Four Dimensional GIS and Its Application to Disaster Monitoring with Satellite Remote Sensing Data, Proceedings of the Conference on GIS and Application of Remote Sensing to Disaster Management, 132-137(1997).

[3] Kohei Arai, An Expectation to Remote Sensing for Disaster Management, Proceedings of the United nation and Japan-US Science/Technology and Space Application Program Joint Symposium on Disaster Management, (1997).

[4] Kohei Arai, The Conference on GIS and Application of Remote Sensing to Disaster Management Four Dimensional GIS and Its Application to Disaster Monitoring with Satellite Remote Sensing Data, Proceedings of the Conference on GIS and Application of Remote Sensing to Disaster Management, 132-137 Greenbelt, Maryland, U.S.A., 1997.

[5] Kohei Arai, The Current Status on Disaster Monitoring with Satellites in Japan, Proc. of the Committee on Earth Observation Satellites/Working Group on Information Systems and Services/Task Team 19 Meeting, Greenbelt, Maryland, U.S.A., 1997.

[6] Kohei Arai, Proc. of the Joint Symposium on Disaster Management Between United Nation and Japan-US Science/Technology and Space Application Program, Hawaii, U.S.A., 1997.

[7] Kohei Arai, An Expectation on Remote Sensing Technology for Disaster Management and Response, United Nations Proceedings Series, Edt.Y.Ogawa and Kohei Arai, No.28, p.11, 1998.

[8] Kohei Arai, Virtual Center for Disaster Management, Proc. of the 2nd United Nation and JUSTSAP Joint Symposium, 1998.

[9] Kohei Arai, Opening Remarks of Satellite Based Disaster Management, Proc. of the Disaster Management Workshop in Ihilani Hotel, Hawaii USA, Invited Speech, 1998.

[10] Kohei Arai, Disaster related activities, Proceedings of the 1st JUSTSAPADRC Joint Symposium on Disaster Management, (1999).

[11] Kohei Arai, Internet GIS and Disaster Information Clearing House, Proceedings of the 1st JUSTSAP-ADRC Joint Symposium on Disaster Management, (1999).

[12] Kohei Arai, Opening address of the disaster management symposium, United nations Center for Regional Development Proceedings, No.34, pp.9-12, (1999).

[13] Kohei Arai, Virtual center for disaster management, United nations Center for Regional Development Proceedings, No.34, pp.33-38, (1999).

[14] Kohei Arai, Joint Research on Disaster Management, Proceedings of the United Nations, Center for Regional Development, UNCRD Headquarter, Nagoya, 7 Jan., 1999.

[15] Kohei Arai, URL search engine with text search tools for disaster mitigation, Proceedings of the Asian Disaster Reduction Center R\&D Project Workshop, Mar.3, (2000).

[16] Kohei Arai, Four-dimensional GIS system through internet, Proceedings of the Asian Disaster Reduction Center R\&D Project Workshop, Mar.4, (2000).

[17] Kohei Arai, Visualization of disaster information derived from Earth observation data, Proceedings of the Asian Disaster Reduction Center R\&D Project Workshop, Aug.31, (2000).

[18] Kohei Arai, Java based image processing and analysis software package, Proceedings of the Japan-US Science, Technology and Space Application Program Workshop, Hiro, Hawaii, (2000). 
[19] Kohei Arai, Internet Geographic Information System (GIS), Proceedings of the Japan-US Science, Technology and Space Application Program Workshop, Hiro, Hawaii, (2000).

[20] Kohei Arai, Disaster related URL search engine with queries in a natural language, Proceedings of the Japan-US Science, Technology and Space Application Program Workshop, Hiro, Hawaii, (2000).

[21] Kohei Arai, Disaster monitoring with ASTER onboard Terra satellite, Proceedings of the Japan-US Science, Technology and Space Application Program Workshop, Hiro, Hawaii, (2000).

[22] Kohei Arai, Clearing house for disaster management, Proceedings of the Japan-US Science, Technology and Space Application Program Workshop, Hiro, Hawaii, Nov.15, (2000).

[23] Kohei Arai, ICT technology for disaster mitigation (Tsunami warning system), Proceedings of the 1st International Workshop on Knowledge Cluster Systems, 2007.

[24] Kohei Arai and Achmad Basuki, Cellular automata-based approach for prediction of hot mudflow disaster area, Proceedings of the International Conference on Computational Science and Its Applications (ICCSA2010), LNCS part-II, 87-98, 2010.

[25] Kohei Arai and Achmad Basuki, Simulation of hot mudflow disaster with cellular automata and verification with satellite imagery data, Proceedings of the ISPRS WG VIII/1 TS-19, 2010.

[26] Kohei Arai, Kiyotaka Fujisaki, Hiroaki Ikemi, Masato Masuya, Terumasa Miyahara, Backup communication routing through Internet Satellite, WINDS, for transmission of disaster relief data, Proceedings of the International Symposium on WINDS Application Experiments, 2010.

[27] Kohei Arai, Backup communication routing through Internet satellite WINDS for transmission of disaster relief data, Proceedings of the International Symposium on WINDS, 2010.

[28] Kohei Arai and Achmad Basuki, Two-dimensional cellular automata approach for disaster spreading, Proceedings of the 18th Indonesian Scientific Meeting, 2010.

[29] Kohei Arai, Disaster Mitigation, Visiting Scholar, World Class University, The Program of Sebelas Maret University, Invited Speaker, 2010.

[30] Kohei Arai, Tri Harsono, Achmad Basuki, Micro traffic simulation with unpredictable disturbance based on Monte Carlo simulation: effectiveness of the proposed agent cars of Sidoarjo hot mudflow disaster, Journal of Emitter, 1, 1, 1-10, 2010.

[31] Achmad Basuki, Tri Harsono and Kohei Arai, Probabilistic cellular automata-based approach for prediction of hot mudflow disaster area and volume, Journal of EMITTER1, 1, 11-20, 2010.

[32] Achmad Basuki and Kohei Arai, Two dimensional CA approach for disaster spreading, Innovation Online (INOVASI), 18,12,19-26, 2010.

[33] Tri Harsono, Kohei Arai, Deceleration in the micro traffic model and its application to simulation for evacuation from disaster area, Proceedings of the IES: Industrial Electronics Seminar, at EEPIS, 1-8, 2011.

[34] Kohei Arai, Cellular automata approach for disaster propagation prediction and required data system in GIS representations, Proceedings of the 1st ICSU/WDS Conference - Global Data for Global Science, 2011.

[35] Kohei Arai, Tri Harsono, Achmad Basuki, Cellular automata for traffic modelling and simulation in a situation of evacuation from disaster areas, Cellular Automata-Simplicity Behind Complexity, Edt. Aiejandro Salcido, ISDN: 978-953-307-230-2, In Tech Publishing Co. Ltd., 193218, 2011.

[36] Kohei Arai, Achmad Basuki, New Approach of Prediction of Sidoarjo Hot Mudflow Disaster Area Based on Probabilistic Cellular Automata, Geo-informatica - An International Journal (GIIJ), 1, 1, 1-11, 2011.

[37] Kohei Arai, Tri Harsono, Achmad Basuki, Cellular automata for traffic modeling and simulation in a situation of evacuation from disaster areas -Cellular automata Simplicity behind Complexity-, Edt. Aiejandro Salcido, ISBN:978-953-307-230-2, In Tech Publishing Co. Ltd., 193218, 2011.

[38] Kohei Arai, Back-up communication routing through Internet satellite WINDS for transmitting of disaster relief data, International Journal of Advanced Computer Science and Applications, 2, 9, 21-26, 2011.
[39] Kohei Arai, Sensor network for landslide monitoring with laser ranging system avoiding rainfall influence on laser ranging by means of time diversity and satellite imagery data-based landslide disaster relief, International Journal of Applied Sciences, 3, 1, 1-12, 2012.

[40] Kohei Arai, T.X.Sang, N.T.Uyen, Task allocation model for rescue disable persons in disaster area with help of volunteers, International Journal of Advanced Computer Science and Applications, 3, 7, 96-101, 2012.

[41] Kohei Arai, Cell based GIS as Cellular Automata for disaster spreading prediction and required data systems, CODATA Data Science Journal, 137-141, 2012.

[42] T.Harsono, Kohei Arai, Deceleration in the evacuation from disaster area, Journal of Electronics, Mechanics \& Robotics, Informatics \& Computer, Telecommunications (EMITTER), 2, 2, 203-210, 2012.

[43] Kohei Arai, Cell based GIS as cellular automata for disaster spreading predictions and required data systems, Advanced Publication, Data Science Journal, Vol.12, WDS 154-158, 2013.

[44] Kohei Arai, Visualization of 5D assimilation data for meteorological forecasting and its related disaster mitigation utilizing VIS5D of software tool, International Journal of Advanced Research in Artificial Intelligence, 2, 9, 24-29, 2013.

[45] Kohei Arai, Vital sign and location/attitude monitoring with sensor networks for the proposed rescue system for disabled and elderly persons who need a help in evacuation from disaster areas, International Journal of Advanced Research in Artificial Intelligence, 3, 1, 24-33, 2014.

[46] Kohei Arai, Method and system for human action detection with acceleration sensors for the proposed rescue system for disabled and elderly persons who need a help in evacuation from disaster areas, International Journal of Advanced Research in Artificial Intelligence, 3, 1, 34-40, 2014.

[47] Kohei Arai, Method and system for human action detection with acceleration sensors for the proposed rescue system for disabled and elderly persons who need a help in evacuation from disaster areas, International Journal of Advanced Research in Artificial Intelligence, 3, 1, 34-40, 2014.

[48] Kohei Arai, Hiroshi Okumura, Shogo Kajiki, Disaster relief with satellite based synthetic aperture radar data, Proceedings of the SAI Future Technology Conference 2017, No.521, 1026-1029, in Vancouver, 2017.

[49] Kohei Arai, Sentinel 1A SAR Data Analysis for Disaster Mitigation in Kyushu, Kyushu Brunch of the Japanese Society on Remote Sensing, Special Lecture for Young Engineers on Remote Sensing, Nagasaki University, 2018.

[50] Kohei Arai, Flooding and oil spill disaster relief using Sentinel of remote sensing satellite data, International Journal of Advanced Computer Science and Applications IJACSA, 10, 12, 290-297, 2019.

[51] Kohei Arai, Convolutional neural network considering physical processes and its application to disaster detection, International Journal of Advanced Computer Science and Applications IJACSA, 10, 12, 105111, 2019.

[52] Kohei Arai, Method for rainfall rate estimation with satellite based microwave radiometer data, International Journal of Advanced Computer Science and Applications IJACSA, 11, 3, 82-91, 2020.

[53] Kohei Arai, Hiroshi Okumura, Shogo Kajiki, Flood Damage Area Detection Method by Means of Coherency Derived from Interferometric SAR Analysis with Sentinel-1A SAR, International Journal of Advanced Computer Science and Applications IJACSA, 11, 7, 88-94, 2020.

\section{AUTHORS' PROFILE}

Kohei Arai, He received BS, MS and PhD degrees in 1972, 1974 and 1982, respectively. He was with The Institute for Industrial Science and Technology of the University of Tokyo from April 1974 to December 1978 also was with National Space Development Agency of Japan from January 1979 to March 1990. During from 1985 to 1987, he was with Canada Centre for Remote Sensing as a Post-Doctoral Fellow of National Science and Engineering Research Council of Canada. He moved to Saga University as a Professor in Department of Information Science in April 1990. He is now an Emeritus Professor of Saga University since 2014. He was a council member for the Aeronautics and Space related to the Technology Committee of the Ministry of 
Science and Technology during from 1998 to 2000. He was a councilor of Saga University for 2002 and 2003. He also was an executive councilor for the Remote Sensing Society of Japan for 2003 to 2005. He is a Science Council of Japan Special Member since 2012. He is an Adjunct Professor of University of Arizona, USA since 1998 and is an Adjunct Professor of Nishi-Kyushu University as well as Kurume Institute of Technology/AI Application Laboratory since 2021. He also is Vice Chairman of the Science Commission
"A" of ICSU/COSPAR since 2008 then he is now award committee member of ICSU/COSPAR. He wrote 60 books and published 640 journal papers as well as 460 conference papers. He received 66 of awards including ICSU/COSPAR Vikram Sarabhai Medal in 2016, and Science award of Ministry of Mister of Education of Japan in 2015. He is now Editor-in-Chief of IJACSA and IJISA. http://teagis.ip.is.saga-u.ac.jp/index.html 